\title{
The Struggle of Communist Society against the Capitalist Society and Religion
}

\author{
Coulibaly Yacouba ${ }^{1}$, Xinmin Gao ${ }^{1}$, Xixiang Sun ${ }^{2}$ \\ ${ }^{1}$ Department of Philosophy, Institute of Marxism School, Central China Normal University, Wuhan, China \\ ${ }^{2}$ Department of Ideology and Political Education, Institute of Marxism School, Central China Normal University, Wuhan, China \\ Email: bayacoulib@yahoo.fr, ccnugxm@126.com, 496590239@qq.com
}

How to cite this paper: Yacouba, C., Gao, X. M., \& Sun, X. X. (2016). The Struggle of Communist Society against the Capitalist Society and Religion. Open Journal of Philosophy, 6, 428-435.

http://dx.doi.org/10.4236/ojpp.2016.64040

Received: October 19, 2016

Accepted: November 8, 2016

Published: November 11, 2016

Copyright $\odot 2016$ by authors and Scientific Research Publishing Inc. This work is licensed under the Creative Commons Attribution International License (CC BY 4.0).

http://creativecommons.org/licenses/by/4.0/

\begin{abstract}
The capitalist system of exploitation of workers opened the door to the process of class conflict and created opposite social class such as bourgeoisie (those who own the means of production in capitalist society) and proletariat (individuals with labor power). That conflict would be solved, according to Marx, through revolutionary struggle. In this conflict, the proletariat will rise up against the bourgeoisie and establish a communist society. Marx and Engels gave some description of communist society: Abolition of property in land, centralization of credit in the hands of the state, centralization of the means of communication and transport in the hands of the state, extension of factories and instruments of production owned by the state, free education for all children in public schools etc. (Boyle \& Marx, 2004). A communist party is a political party that advocates the application of the social and economic principles of communism through state policy.
\end{abstract}

\section{Keywords}

Struggle, Communist Society, Capitalist Society, Religion

\section{Introduction}

The name of communist party originates from the 1848 tract manifesto of the communist party by Marx and Engels in the half of the 19th century (Marx \& Engels, 1948). They wanted to end capitalism thought that led to the exploitation of workers and set a new society of freedom. The capitalist society is a society of exploitation and injustice. The main purpose of communism struggle is to create a society of justice and abolish the exploitation ${ }^{1}$. In bourgeoisie society, the value of human being is determined by material possession and not moral quality or intellectual ability (John, 1976). Money is

${ }^{1}$ The communist Manifesto, classics in politics: Marx and Engels, Elecbook, p. 27. 
the soul of capitalist society, its divinity (Marx, 1961).

Somehow, we can say that the battle of Marx and Engels is a battle of righteousness, equality in society between men. That's why the capitalist or bourgeoisie society became the target. Because in that society injustice is the daily reality (Brunhoff, 2001). The same way, because of the passivity of religious leaders regard to that injustice and their "association" with political leaders, the religion became the other target ${ }^{2}$. The silence of religion regard to the exploitation of proletarians is intolerable for Marx and Engels (Lü, 2014). They became hurt when the religion leaders try to discourage proletarians to undertake revolutionary actions against bourgeoisie. Then Marx and Engels had to struggle against both capitalist society and religion ${ }^{3}$.

We should understand that the attitude of Marx regarding to the religion has some other reasons such as the family background, historic background and the political background. Understanding the previous reasons help any researcher to avoid the prejudice and to build a scientist thought while thinking about Marx and his works. In this article, we will give deep explanation for the sake of clarity. To achieve our goal, we will give a clear picture of the capitalism society, explain the background of Marx views about religion, and give some perspectives based on the above analysis.

\section{Capitalist Society and Social Relations}

Marx describes the super power of money in capitalist society as the most important thing. Money is better than everything and everybody including the owner of the money. It determines the social value and the moral value. Even the physical value (beauty) of men in bourgeoisie society is determined by money. Marx wrote: "That which is for me through the medium of money-that for which I can pay (i.e., which money can buy)-that am I myself, the possessor of the money. The extent of the power of money is the extent of my power" (Marx, 1964).

Money is at the same time the soul, the spirit and the body of man in the capitalist society; it is the law and the norms, the ability and the essence of people. Marx wrote in the same text: "Thus, what I am and am capable of is by no means determined by my individuality. I am ugly, but I can buy for myself the most beautiful of women. Therefore I am not ugly, for the effect of ugliness-its deterrent power-is nullified by money" (Limen).

Money has power to change people and provide unto them the value they don't have (Jordan, 1992). It changes dishonest people into honest ones. Because of money, a brainless can buy clever people for himself. Bourgeoisie has changed the social relations into relation of production (Jenkins, 1913). Man has stopped to consider his fellow man as neighbor because of the perspective of the new society. The blood doesn't determine family relationship anymore. The role people play in the system of production is the main criterion, for the social classes are founded on the economy or the material possessions (Marx, 2010). In the process of production, human beings work in one hand

${ }^{2}$ Le Marxisme, théorie et pratique de la révolution, 2 éd, p. 29.

${ }^{3}$ Economic and philosophic manuscripts of 1844 . 
upon nature, and another hand upon one another. Bourgeoisie has established a system of exploitation in which rich people get richer and poor people get poorer (Brunhoff, 2001). According to Marxist perspective, this contradiction will only end by revolution. The mission of communist society is to abolish all forms of social barrier and establish unity and equality. Communist society is a new hope for hopeless people (Marx, Engels, \& Lenin, 1975).

\section{The Background of Marx's Views on Religion}

\subsection{Family Background}

The family context of Marx is very crucial for researchers to understand his attitude and his view about religion. Third child of a family of nine, one died at birth and another four from tuberculosis between 11 and 36 years old. Marx grew up in a family of Jewish origin. His paternal grandfather, named Marx-Levy was a rabbi in Trier; his mother also came from a family of rabbis ${ }^{4}$.

In 1815 Discrimination of the Prussian government say in $1824^{5}$. The conversion of the family of Marx was only a formality imposed by the Prussian government. They became Christian not by conviction but by pressure (Guichard, 1972).

\subsection{Politico-Historical Context}

The time Marx was determined in his fight against social injustice; he realized that the church leaders were playing double game instead of fighting injustice. Somehow the Prussian Government was using religion as a mask to oppress people especially proletarian class. In 1839, Feuerbach said: "Theology is the only practical and efficient vehicle used by politics, at least for this moment". That put emphasis on the cooperation between politics and religion. In 1840 when Frederic-Guillaume IV became king, the confusion between politics and Religion become worst. Through Julius Von Stahl, his counselor, the theory of Christian State ${ }^{6}$ was presented openly and officially. The religion was used as a simple forbade Jewish access to public service (Prussia (Kingdom)). The Racial discrimination measures are to prohibit the liberal Jewish functions like legal profession. Thus Herschel, Marx's father will choose between his faith and his profession. Then he converted to Protestantism and took the name of Heinrich. His wife and children will follow him later. Marx received the Protestant baptism at the age of 6 years that is to say that they became Christians without conviction of salvation rather to avoid persecution.

The confusion between religion, politics and philosophy was so obvious that at the same time religion appears as part of philosophy through Hegel and part of politics through political leaders. Marx was openly against that Christian State because it did not make sense. Christianity preaches Love and Justice and the Prussian Government shows up the contrary by action but still there is a possible covenant between both politics and Religion.

\footnotetext{
${ }^{4}$ Le Marxisme, théorie et pratique de la révolution, 2 éd, p. 19.

${ }^{5}$ Ibid, p. 19.

${ }^{6}$ Jean-Yves Calvez, La pensée de Karl Marx, Ed. Seuil, 1956, page 59.
} 
The existence of social classes increased also the practice of injustice in Society between men and divided them into enemies. Marx was convinced that the solution would be in the suppression of social classes (Cornu, 1948). But, Because of the link between religion and political reaction, Marx had to fight against the reactionary Prussian state and the Church as well. The history reveals that the church remained complicit in the oppression even after Marx.

\section{Marx’s Religion Critics}

In this portion we will talk about the reasons that explain the attitude of Marx concerning the religion and religious leaders. We will talk basically on the family background, politico-historical implication. Then we will go through statements such as: "Religion is the opium of the people"; "Religion is the expression of the distress of the people”. From a systematic approach, we'll show how Marx was wrongly blamed by his critics. The next issue will help us to illuminate our evidence:

\subsection{Religion as Opium of the People}

Marx present the religion in this frame: "Religious suffering is, at the same time, the expression of real suffering and a protest against real Suffering. Religion is the sigh of the oppressed creature, the heart of a heartless world, and the soul of soulless conditions. It is the opium of the people" (Marx \& O'Malley, 1970). Knowing well that spiritual power is not the domain of rationality, then Marx made alert. As other form of ideology, belief can blind the believer and prevent him to be conscious to the danger in which he or she is exposed. Even though some authors try to combat the ideology of Marx, it is better to take time to understand Marx (North, 1968).

Saying that religion is the opium of the people, Marx wanted to draw the attention of men on the manipulations that religious leaders could exercise over the believers in the name of God. To Marx religion is illusory happiness or short happiness and not the happiness that last. Somehow he sees the religion like a big hole that delay the realization of true freedom. That's why according to him, religion should disappear so that men could face their real situation and find the way to go out of it. According to Marx, religion is an expression of material realities and economic injustice. Thus, problems in religion are ultimately problems in society. Religion is not the disease, but merely a symptom. It is used by oppressors to make people feel better about the distress they are experiencing because of poverty and being exploited.

The above thought explained the origin of his comment against religion when he says for example "Religion is opium of the people" - but, his thoughts are much more complex than commonly portrayed. The ultimate purpose of the struggle is emancipate human being and not let him be in the midst of utopian's dream. The battle may be long but it should set free human being from alienation. In religion people make their empirical world into an entity that is only conceived, imagined, that confronts them as a mystery (Marx, Engels, Arthur, \& Marx, 1972). 


\subsection{Religion as Expression of the Distress of the People}

Wondering himself about the value and the real meaning of religion, Marx discovers in it a double meaning: it is both an illusion that makes man asleep and keeps him in his daily misery; but it is also the hope for a better world that will announce the end of the misery of unfortunate people. His argument is as follows: initially it will define religion as a collective representation that men internalize. Then, it highlights the function of this collective representation. That puts light on the real stakes of this critics of religion.

If you follow the logic of Max about religion as conceived by Marx, it pretends to come to the man's rescue when in reality its survival depends on the sustainability of human misery (John, 1976). Its function is to explain and make sense of the world in which we live. It targets this purpose, more, specifically it is unfortunate to say to those who are undergoing through the shameless exploitation of their similar, social injustice. Its mission is to give an appearance of spirituality in a materialistic world that alienates men, that is to say that religion objectifies men (turns men into things). But in reality, it aims to maintain this unfortunate situation. According to Marx, the mission of religion is not to change but to pretend to change. Religion is a lie that allows us to endure the world in which we live. It is in this sense that we must understand this expression: "Religious distress is at the same time the expression of real distress and the protest against real misery... It is the opium of the people." Many people engage in religion to escape from any situation that weighs. The typical example of Marx was his own family who became Christian because of anti-Semitism that threatened Jews.

The transition from Jewish to Christian Lutheran confession was a milestone in the life of the future scientist. Based on his own situation he examines the general pattern that causes men to conversion. This question of Marx was an opportunity for every believer to sincerely probe by questioning the true motives of his conversion. If at some point in life everyone wondered about the true motives of his faith, many would realize that they have a wrong faith. But unfortunately, when you point to the sun, the ignorant instead of looking at the direction of the finger, merely watches the finger ${ }^{7}$. Marx does not just deny religion, but it reveals some sad truths about religion.

Taking this into consideration can save a believer from fanaticism and fake faith. Religion is a heaven for many believers. They use religion as an outlet means of a temporary crisis. The fact that some theologians present God with contradictory attributes should obviously let us understand that there is a problem of interpretation. The scriptures are true, but interpretations are usually wrong.

\section{Perspectives}

Marx's theories up to now have been misunderstood and misinterpreted either because of ignorance or because of bad faith of his detractors. He was described as demon by religious, revolutionary politicians. However, Marx has remained faithful to his battle. Was it necessary to wait for some centuries for the relevance of Marx's ideas to be re-

${ }^{7}$ Saying in Mali which means that we should search the real meaning and not to hold on superficial context only. 
vealed as the sun at the Zenith? We can understand that Marx was ahead of his time so that his contemporaries could not understand the truth of his ideas. The analysis made by Marx on religion, politics, capitalism, and many other areas are indisputable today.

Should we see in Marx an atheist or someone exposing the adventures of religion?

If we refer to the first signification of atheist as the denial of God, Marx is no doubt an atheist (Blackford \& Schuiklenk, 2009). In the struggle of the liberation of the poor, he describes the religion (Christianity) as a barrier in the sense that the fundamental teachings of the Church are based on love. So according to Marx the abolition of religion as the illusory happiness of the people is the demand for their real happiness. However there is another aspect in the Marxist view of religion. In his rationalist critique of religion, Marx is relentless. He believes that God and the gods are only illusions we encounter in unoccupied areas by reason. This means that religion disappears with reason. Here it is clear that Marx was an atheist. In his doctoral dissertation, Marx adopted as his motto the words of the Greek hero Prometheus who defied the gods to bring fire to humanity: "I hate all gods," with addition that they "do not recognize man's self-consciousness as the highest divinity."

In this study we want to put emphasis on Marx's analysis about religion and religious leaders (Table 1). Then we can make a comparison with our reality. If we look at Christianity and Islam we can see in both proof of Marx's statement such as: "Religion is opium of the people", "Religion is expression of the distress of the people". Actually religion take away people from God and make them slaves of other men. Many believers are living in slavery because of the nature of teaching they are receiving. Christianity and Islam are today two major confused domain nowadays.

Nowadays looking at the rise of terrorism in all its forms; we must know that time has come to recognize that Marx did not make a non-sense statement. No need to turn around to find out, it's so obvious. Because of funny interpretations of religious texts we see instabilities everywhere in the world. Often it is difficult to distinguish the personal interests from what the scriptures really mean. That make difficult to know exactly what God really required. Sometime we wonder who is speaking, man or God. The proof is that the teachings are contradictory even though the same book is used as source of the inspiration. The same people preaches a God of love in peaceful time and a monstrous God in times of depression. The same God is sometimes merciful so that He saves unconditionally and often offers salvation at the cost of innocent lives (terrorists mind). We must kill a thousand people and commit suicide then to be sure of being saved.

Table 1. View of marx and nowadays reality.

\begin{tabular}{cc}
\hline $\begin{array}{c}\text { Religion is opium of the People } \\
\text { Religion is expression of the distress } \\
\text { Religion pretend to help People } \\
\text { Religion promote hatred } \\
\text { Religion cheat people }\end{array}$ & The recruitment of DAESH and others \\
Prosperity Churches \\
Bombing innocent people
\end{tabular}


Sometimes, the Lord's army launched the battle against demons and principalities of darkness; sometimes it is innocent children incorporated by force into an army to kill their families and strangers in the name of the Lord. The same way, Koran presents a Merciful God but after its reading, terrorists get on the road and destroy people and goods by saying Allah Akbar (God is great) or before slaughtering other children of God in the name of God.

Worst, many of religious leaders are involved in politics not because of political conviction but only because they are more interested in (material welfare) than things from above (heaven). In the name of religion they are ready to die for the sake of temporary interest. God is not a man or a son of man to lie or change his mind.

For example the church was complicit in slavery and colonization in South America, also the Catholic hierarchy was one of the main walls of military regimes. In South Africa, the Dutch Reformed Church taught the Afrikaners that they were the "chosen people" and those blacks were an inferior race. There is a saying in Mali said: "We cannot slap the chicken and wanting to spare its eyes. The passive nature of church leaders to exploitation of the proletariat, according to Marx, was not acceptable". Marx was convinced that only revolution could change the trend. And This Marxist perception was incompatible with the central message of the church focus on: the love of neighbor which refers to both those who hate us and those who treat us well.

In his humanist critique of religion under the influence of Feuerbach, Marx also presents its views. Instead of religion disappears in his contact with the reason, that contact should be the beginning of disillusion process that occurs. The alienated man disillusioned in God through the denial of God and then gradually up to the state of the transparent man himself.

In the third phase Marx speaks of the negation of the negation that is to say the rejection of atheism. For Marx, atheism must be exceeded as it is still a mediator between man and himself. Marx believes that atheism is a passage in the process of man's desalination, but not an end in itself. Indeed, atheism is a negation of God, and from that negation the existence of man becomes reality. In the 18884 manuscripts, this one reads an atheist state is still a religious state, "Man even if he proclaims himself an atheist through the state, that is to say, even if it proclaims the state as an atheist, this man is still embraces religion... Religion is precisely the recognition of man in a roundabout".

\section{Conclusion}

From the argumentation above, we can see clearly that the struggle of communist society against bourgeoisie is to establish freedom, equality and justice among humans. It is also to renew the hope of hopeless, abolish the yoke of exploitation. The mission of communism is to redefine the nature of social relationship. To fulfill such mission, the bourgeoisie society must disappear completely. Because religious leaders were complicit of bourgeoisie then religion will not escape from the court of communist society. We can say that Marx's critics' against religion and religious practices is rather a warning. According to Marx, the function of religion was double played: If the real 
function of religion was to make the best world, why does the world goes from bad to worse? Today homosexuals have managed to win the support of religion defending their case fully. Religion has become a source of terror and instability in the world. The Islamic state is preaching with grenades in one hand and the sword in the other. Isn't true that Karl Marx has become today a scholar and "prophet"?

\section{References}

Blackford, R., \& Schuiklenk, U. (2009). 50 Voices of Disbelief: Why We Are Atheists. Chichester, West Sussex; Malden, MA: Wiley-Blackwell. http://dx.doi.org/10.1002/9781444307986

Boyle, D., \& Marx, K. (2004). The Communist Manifesto. Hauppauge, NY: Barron's.

Brunhoff, S. de (2001). Bourgeoisie: État d'une classe dominante. Paris: Syllepse.

Cornu, A. (1948). Karl Marx et la Révolution de 1848. Paris: Presses universitaires de France.

Guichard, J. (1972). Le marxisme; théorie et pratique de la révolution (3rd éd. revue et cor. ed.). Lyon: Chronique sociale de France.

Jenkins, C. A. (1913). Humanite Society. The Power of Money to Control. Indirect Taxation. Transportation. Land. Money. Trust Centralization. San Francisco, Cal.: Printed by Eastman \& Co.

John, P. M. (1976). Marx on Alienation: Elements of a Critique of Capitalism and Communism. Calcutta: Minerva Associates.

Jordan, B. (1992). The Power of Money. Brooklyn, NY: Zoe Ministries.

Limen, N. G. The Power of God Is More than the Power of Money. Bamenda: Limen Spiddy Phrobert.

Lü, D. (2014). Marxism and Religion. Boston: Brill.

Marx, K. (1964). Economic and Philosophic Manuscripts of 1844. New York: International Publishers.

Marx, K. (2010). Essential Writings of Karl Marx: Economic and Philosophic Manuscripts, Communist Manifesto, Wage Labor and Capital, Critique of the Gotha Program. St Petersburg, Fla.: Red and Black Publishers.

Marx, K., \& Engels, F. (1948). The Communist Manifesto (Centennial Ed.). New York, NY: New York Labor News Co.

Marx, K., \& O’Malley, J. J. (1970). Critique of Hegel's “Philosophy of Right”. Cambridge Eng.: University Press.

Marx, K., Engels, F., \& Lenin, V. I. (1975). Marx, Engels, Lenin: The Humanism of Communist Society. Moscow: Novosti Press Agency Pub. House.

Marx, K., Engels, F., Arthur, C. J., \& Marx, K. (1972). The German Ideology. New York: International Publishers.

Marx, Karl. (1961). Economic and Philosophic Manuscripts of 1844. Moscow: Foreign Languages Publishing House.

North, G. (1968). Marx's Religion of Revolution; The Doctrine of Creative Destruction. Nutley, NJ: Craig Press.

Prussia (Kingdom). Prussian Government Records, 1686-1849 (p. 2). 
Submit or recommend next manuscript to SCIRP and we will provide best service for you:

Accepting pre-submission inquiries through Email, Facebook, LinkedIn, Twitter, etc. A wide selection of journals (inclusive of 9 subjects, more than 200 journals)

Providing 24-hour high-quality service

User-friendly online submission system

Fair and swift peer-review system

Efficient typesetting and proofreading procedure

Display of the result of downloads and visits, as well as the number of cited articles

Maximum dissemination of your research work

Submit your manuscript at: http://papersubmission.scirp.org/

Or contact ojpp@scirp.org 